\title{
Effects of three microbial probiotics on postprandial porto- arterial concentration differences of glucose, galactose and amino-nitrogen in the young pig
}

\author{
BY G. RYCHEN* AND C. SIMÕES NUNES† \\ Centre de Recherche en Nutrition Animale, Société Chimique Roche, BP 170, \\ 68305 Saint-Louis Cedex, France
}

(Received 6 September 1993 -Revised 13 October 1994 - Accepted 16 November 1994)

\begin{abstract}
Postprandial kinetics of porto-arterial concentration differences of glucose (G), galactose (Gal), L-lactic acid (LA) and amino-N (AN) were studied in the piglet after the ingestion of $10^{7}$ colony-forming units (cfu) Sporolactobacillus P44 (SP), or $10^{6}$ cfu Bacillus cereus IP5832 (AC), or $10^{6}$ cfu of a combination of Lactobacillus acidophilus, $L$. fermentum and $L$. brevis (AB)/g feed. Sixteen fistulated piglets (portal vein and brachiocephalic trunk; mean body weight 22 (SD 2) kg) were used. The diet was based on skimmed milk $(320 \mathrm{~g} / \mathrm{kg})$, barley $(300 \mathrm{~g} / \mathrm{kg})$, wheat bran $(110 \mathrm{~g} / \mathrm{kg})$, maize $(100 \mathrm{~g} / \mathrm{kg})$ and lactose $(70 \mathrm{~g} / \mathrm{kg})$. The postprandial blood kinetics, four measurements per animal at 1-week intervals, were studied for $6 \mathrm{~h}$ after the ingestion of test meals of $400 \mathrm{~g}$ basal diet (BD) or this diet supplemented with the bacteria (SP, AC and AB respectively). Areas of porto-arterial concentration differences (APACD) of G, Gal and LA were not influenced by the bacteria supplements. APACD of AN was significantly higher after the ingestion of the SP diet than that estimated for BD.
\end{abstract}

Probiotic: Absorption: Glucose: Amino-nitrogen: Piglet

Public misgivings about side-effects that often follow the use of antibiotics as growth promoters and therapeutic agents are at the origin of the probiotic concept and have strongly stimulated its development (Fuller, 1992). There is, therefore, a growing demand for an effective alternative to antibiotic growth promoters, and microbial probiotics could probably fill the gap.

Favourable changes, induced by microbial probiotics, in the activity of the digestive microflora have been described (Nguyen et al. 1988; Pusztai et al. 1990; Vanbelle et al. 1990). It has been demonstrated that lactobacilli exert various metabolic activities in the gut. Hill et al. (1970) observed that ingestion of lactobacilli significantly reduced intestinal and urinary amines in the pig. Ayebo et al. (1980) and Goldin et al. (1980) measured lower levels of $\beta$-glucuronidase $(E C 3.2 .1 .31)$ and $\beta$-glucosidase $(E C 3.2 .1 .21)$ activity in human faeces when lactobacilli were added to the diet. Muralidhara et al. (1977), Barrow et al. (1980), and Ratcliffe et al. (1986) observed modifications of the gut microbial balance in piglets after lactobacilli ingestion, in particular decreased counts of coliforms in the intestinal tissue and faeces. The beneficial effects of yoghurt, which contains Lactobacillus bulgaricus and Streptococcus thermophilus, on lactose digestion has been demonstrated by Kim \& Gilliland (1983), Garvie et al. (1984), Kolars et al. (1984) and Marteau et al. (1990). The presence of yoghurt micro-organisms in the gut resulted in a stimulating effect on the intestinal lactase (EC 3.2.1.23) activity (Besnier et al. 1983; Schaafsma et al. 1988). Recently we demonstrated that Sporolactobacillus P44 (Bel Industries, Vendôme, France)

* Present address: ENSAIA, Sciences Animales, BP 172, 54005 Vandoeuvre-les-Nancy Cedex, France.

+ For reprints. 
ingested by the growing-fattening pig ( $70 \mathrm{~kg}$ body weight) at $10^{7}$ colony-forming units (cfu)/g of a feed rich in lactose, increased apparent intestinal absorption of glucose, galactose and amino-N (Rychen \& Simões Nunes, 1993). The questions arising were, on the one hand, whether such effects could be observed in younger pigs having important endogenous lactase activity and, on the other hand, whether other potentially interesting bacterial strains could induce similar effects. Thus, the main aim of the present work was to study, in the weaner pig, the postprandial kinetics of porto-arterial plasma concentration differences of glucose, galactose, L-lactic acid and amino- $\mathrm{N}$ after ingestion of Sporolactobacillus P44, Bacillus cereus IP5832 (Paciflor ${ }^{\star}$, Prodeta, 56000 Vannes, France) and a combination of Lactobacillus acidophilus, L. fermentum and L. brevis.

\section{MATERIALS AND METHODS}

\section{Animals and diets}

Sixteen castrated male Large White piglets (mean body weight 22 (SD 2) $\mathrm{kg}$ ) were used. Each animal was fitted with two catheters, one placed in the portal vein and one in the brachiocephalic artery as described by Simões Nunes et al. (1989). Surgery was done under very strict aseptic conditions, taking into account the aim of the experimental work. The animals were not given antibiotics during or after surgery. To prevent obstruction by blood clots the cannulas were rinsed daily with a heparinized $(100 \mathrm{IU} / \mathrm{ml}) \mathrm{NaCl}$ solution $(9 \mathrm{~g} / \mathrm{l})$. This was also done under strict aseptic conditions to avoid any risk of infection. The animals generally began to eat $1-2 \mathrm{~d}$ after the operation and rapidly recovered their normal growth rate. After surgery the animals received $400 \mathrm{~g}$ (twice daily) of either the mash basal diet (BD) or BD supplemented with Sporolactobacillus P44 at $10^{7} \mathrm{cfu} / \mathrm{g}$ (SP), or Bacillus cereus IP5832 at $10^{6} \mathrm{cfu} / \mathrm{g}$ (AC) or the combination of lactobacilli at $10^{6} \mathrm{cfu} / \mathrm{g}$ (AB) according to the experimental design described below. The diet was based on maize, barley, skimmed milk and lactose, and contained $166 \mathrm{~g}$ crude protein $/ \mathrm{kg}$ and $12.49 \mathrm{~kJ}$ digestible energy/g (Table 1). The supplemented diets were manufactured weekly at our facilities in order to achieve the requested minimal level of $\mathrm{cfu} / \mathrm{g}$ feed, and stored at $4^{\circ}$. To avoid subsequent added-bacteria losses the supplemented feed was utilized within 1 week of preparation. Furthermore, added-bacteria counts in the feed were systematically checked by an epifluorescence technique belonging to Bel Industries for Sporolactobacillus P44, by numerations on a Mossel medium for Bacillus cereus IP5832, and by numerations on an MRS medium for the lactobacilli. The actual lowest and highest bacterial concentrations $(\mathrm{cfu} / \mathrm{g})$ in the supplemented diets were: $9 \times 10^{6}$ and $3 \times 10^{7}$ for SP; $2 \times 10^{6}$ and $5 \times 10^{6}$ for $\mathrm{AC} ; 9 \times 10^{5}$ and $5 \times 10^{6}$ for $\mathrm{AB}$. Lactose, glucose, galactose and amino-N contents of the four diets were determined after a storage period of $8 \mathrm{~d}$ (Table 2). On a weight basis the included bacteria represented 1/1000 of the supplemented diets. The experimental period began when the piglets had completely recovered from surgery $(8 \mathrm{~d})$. Throughout the experimental period the animals were individually housed in cages which permitted easy access to the cannulas. After surgery and under the feed restriction the piglets' mean daily weight gain was 272 (SD 60) g.

\section{Measurements}

The experimental design over a 4-week period was as follows: four piglets were given diet $\mathrm{BD}$, four diet SP, four diet AC and four diet $\mathrm{AB}$.

Postprandial portal and arterial plasma concentration kinetics and porto-arterial concentration differences of glucose $(\mathrm{G})$, galactose (Gal), amino-N (AN), and L-lactic acid (LA) were evaluated. The sampling protocol was carried out four times for each animal at 1 -week intervals. The observation period lasted for the first $6 \mathrm{~h}$ after ingestion of a $400 \mathrm{~g}$ test meal, preceded by a fasting period of $24 \mathrm{~h}$. Portal vein blood and brachiocephalic trunk 
Table 1. Composition of the basal diet $(\mathrm{g} / \mathrm{kg})^{*}$

\begin{tabular}{lc}
\hline \hline Skimmed milk & 320 \\
Barley & 300 \\
Wheat bran & 110 \\
Maize & 100 \\
Lactose & 70 \\
Wheat-straw meal & 50 \\
Lard & 20 \\
Vitamin and mineral mixture & 30 \\
\hline
\end{tabular}

* Calculated content $(\mathrm{g} / \mathrm{kg})$ : crude protein 166 , digestible energy $12 \cdot 49 \mathrm{~kJ} / \mathrm{g}$, crude fibre $47 \cdot 3, \mathrm{Ca} 9 \cdot 5, \mathrm{P} 7 \cdot 3$, lysine $11 \cdot 9$, methionine $6 \cdot 4$.

Table 2. Lactose, glucose, galactose and amino-nitrogen content $(\mathrm{g} / \mathrm{kg})$ of the experimental diets after a storage period of $8 d$

\begin{tabular}{lcccc}
\hline \hline & BD & SP & AB & AC \\
Diet ... & & & & \\
\hline Lactose & 220 & 220 & 220 & 220 \\
Glucose & $4 \cdot 7$ & $5 \cdot 0$ & $4 \cdot 9$ & $5 \cdot 0$ \\
Galactose & $0 \cdot 4$ & $0 \cdot 4$ & $0 \cdot 4$ & $0 \cdot 4$ \\
Amino-nitrogen & $\operatorname{Tr}$ & $\operatorname{Tr}$ & $\operatorname{Tr}$ & $\operatorname{Tr}$ \\
\hline
\end{tabular}

BD, based diet; SP, BD supplemented with Sporolactobacillus P44; AB, BD supplemented with a combination of Lactobacillus acidophilus, L. fermentum and L. brevis; AC, BD supplemented with Bacillus cereus IP5832; Tr, trace.

blood were sampled simultaneously $(5 \mathrm{ml} / \mathrm{site})$. The samples were withdrawn at intervals of $30 \mathrm{~min}$ during the first $3 \mathrm{~h}$ after the meal and hourly thereafter. Plasma samples were rapidly prepared by centrifugation $\left(2500 \mathrm{~g}, 4^{\circ}, 10 \mathrm{~min}\right)$ and stored at $-20^{\circ}$ until the assays, which were performed within 1 month after the experiment. G and LA were measured with commercial assay systems (Cobas Fara, Roche Diagnostic Systems, Neuilly-sur-Seine, France) as was Gal (Boehringer Mannheim, Meylan, France; Uvikon 930, Kontron Instruments, Birsfelden, Switzerland). AN was determined according to Palmer \& Peters (1969) and Rérat et al. (1987). Plasma concentration values were calculated taking into account the packed cell volume measurements which were carried out throughout the $6 \mathrm{~h}$ observation period. The packed cell volume ranged from 27 to $34 \%$ without any apparent influence of the sampling on the relative part of plasma in whole blood.

\section{Calculations}

Postprandial kinetics of each variable in portal vein and arterial plasma were determined as well as postprandial kinetics of porto-arterial concentration differences. The area between the curve of portal vein plasma kinetic and that of the artery plasma kinetic is indicative of the apparent absorption. This area (APACD) was calculated during the first 3 and $6 \mathrm{~h}$ after feed ingestion for all the variables. Statistical analysis (Snedecor \& Cochran, 1967) of APACD involved calculation of the mean and SD as well as a two-factor hierarchical ANOVA. The mathematical model was:

$$
\mathrm{Yijk}=\mu+\mathrm{Ai}+\mathrm{Bij}+\mathrm{Zijk},
$$

where $\mu$ is the mean, $\mathrm{Ai}$ is the diet effect, $\mathrm{Bij}$ is the combined effect of the diet and animal 

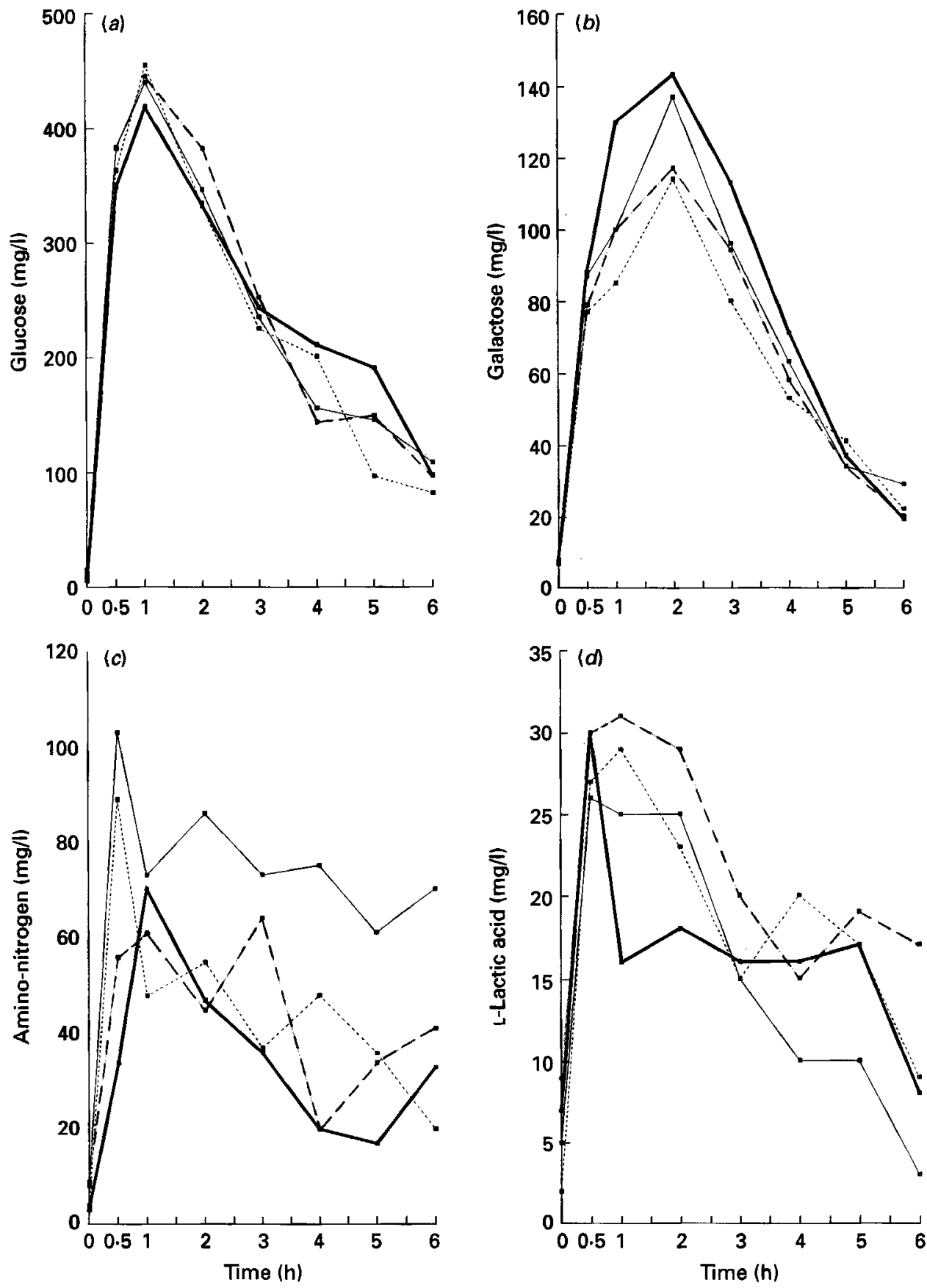

Fig. 1. Kinetics of porto-arterial differences of $(a)$ glucose $(\mathrm{mg} / \mathrm{l}),(b)$ galactose $(\mathrm{mg} / \mathrm{l}),(c)$ amino-nitrogen $(\mathrm{mg} / \mathrm{l})$ and $(d)$ L-lactic acid $(\mathrm{mg} / \mathrm{l})$ in the young pig after ingestion of a basal diet (BD) or the same diet supplemented with various probiotics.,- BD; ——, BD supplemented with Sporolactobacillus P44; ---, BD supplemented with a combination of Lactobacillus acidophilus, L. fermentum and L. brevis; --.--, BD supplemented with Bacillus cereus IP5832. Each point is the mean of sixteen determinations. 
and Zijk is the residual term. The ANOVA was followed by Duncan's multiple range test when a significant $\mathrm{Ai}$ effect without $\mathrm{Bij}$ effect was observed. These calculations were performed using the Statistical Analysis System (SAS Institute, Cary, NC).

\section{RESULTS}

\section{Kinetics of porto-arterial concentration differences}

The kinetics of porto-arterial concentration differences of G, Gal, AN and LA are presented in Fig. 1. Before ingestion of the meal these differences were close to zero for G, Gal and AN and small for LA and very similar for all the treatments. At the end of the observation period porto-arterial differences of Gal returned to the basal level whilst those of the other variables remained higher than the preprandial levels, indicating that the appearances in the portal vein were not finished.

The porto-arterial differences of G (Fig. 1(a)), Gal (Fig. 1(b)) and LA (Fig. 1(d)) were not influenced by the bacteria supplements. Those of AN (Fig. 1(c)) were systematically higher after ingestion of the SP-supplemented diet.

\section{Areas of porto-arterial concentration differences}

Mean treatment values of APACD for each variable are presented in Table 3. It appeared that $\mathrm{G}, \mathrm{Gal}$ and LA apparent absorption values were not modified by the addition of bacteria to the diet. Net appearance of AN in the portal vein after SP intake was significantly higher than that estimated after BD intake (Ai effect for AN APACD measured for the first $3 \mathrm{~h}$ postprandially $(P<0.05)$ and for the whole observation period $(P<0.01))$. The $3 \mathrm{~h}$ and the $6 \mathrm{~h}$ AN APACD after the SP meal represented 169 and $198 \%$ respectively, of those measured for $B D$. The AN APACD after AB and AC meals were not

Table 3. Mean areas of glucose, galactose, amino-nitrogen and L-lactic acid porto-arterial concentration differences $\left(A P A C D, \mathrm{~mm}^{2}\right)$ in the young pig, $3 \mathrm{~h}$ and $6 \mathrm{~h}$ after ingestion of a basal diet or the same diet supplemented with various probiotics*

\begin{tabular}{cccccc}
\hline Diet $\ldots$ & BD & SP & AB & AC & SEM \\
\hline Glucose & $5745^{\mathrm{a}}$ & $5997^{\mathrm{a}}$ & $5862^{\mathrm{a}}$ & $5964^{\mathrm{a}}$ & $445 \cdot 8$ \\
APACD3 & $9059^{\mathrm{a}}$ & $8733^{\mathrm{a}}$ & $8561^{\mathrm{a}}$ & $8753^{\mathrm{a}}$ & $706 \cdot 0$ \\
APACD6 & & & & & \\
Galactose & $2113^{\mathrm{a}}$ & $1899^{\mathrm{a}}$ & $1815^{\mathrm{a}}$ & $1694^{\mathrm{a}}$ & $213 \cdot 5$ \\
APACD3 & $3149^{\mathrm{a}}$ & $2849^{\mathrm{a}}$ & $2697^{\mathrm{a}}$ & $2551^{\mathrm{a}}$ & $260 \cdot 2$ \\
APACD6 & & & & & \\
Amino-nitrogen & $832^{\mathrm{c}}$ & $1408^{\mathrm{d}}$ & $1065^{\mathrm{cd}}$ & $1131^{\mathrm{cd}}$ & $125 \cdot 5$ \\
APACD3 & $1324^{\mathrm{a}}$ & $2618^{\mathrm{b}}$ & $1762^{\mathrm{ab}}$ & $1832^{\mathrm{ab}}$ & $254 \cdot 5$ \\
APACD6 & & & & & \\
L-Lactic acid & $357^{\mathrm{a}}$ & $389^{\mathrm{a}}$ & $478^{\mathrm{a}}$ & $422^{\mathrm{a}}$ & $52 \cdot 3$ \\
APACD3 & $631^{\mathrm{a}}$ & $585^{\mathrm{a}}$ & $782^{\mathrm{a}}$ & $728^{\mathrm{a}}$ & $87 \cdot 1$ \\
APACD6 & & & &
\end{tabular}

BD, basal diet; SP, BD supplemented with Sporolactobacillus P44; AB, BD supplemented with a combination of Lactobacillus acidophilus, L. fermentum and L. brevis; AC, BD supplemented with Bacillus cereus IP5832.

a, b Mean values within a row with unlike superscript letters were significantly different, $P<0 \cdot 01$.

c,d Mean values within a row with unlike superscript letters were significantly different, $P<0.05$.

* For details of diets and procedures, see Table 1 and pp. 20-21. 
significantly different from that measured for BD. It should be emphasized that no treatment-animal interaction effect (Bij) was observed for any of the variables studied.

\section{DISCUSSION AND CONCLUSION}

The results obtained in the present study are discussed on the assumption that portal blood flow was not significantly affected by individual variation or by addition of the bacteria. It is known that meal ingestion is followed by a small rise in portal blood flow during the first 1-2 postprandial hours (Simões Nunes et al. 1989). Individual variations in pig portal blood flow have been established at between 2.8 and $5.7 \%$ (Simões Nunes et al. 1989, $1992 a, b)$. Furthermore, such variations in the portal blood flow were independent of the nature of very different experimental diets. One can easily assume that portal blood-flow variations in the present work were of the same range of amplitude as those observed previously, as well as similar for all the animals, and that they consequently interfered in the same way for all the four dietary treatments.

Microbial probiotics are thought to induce favourable changes in the activity of the digestive microflora (Nguyen et al. 1988; Pusztai et al. 1990; Vanbelle et al. 1990). Pig endogenous lactase activity is relatively important in weaner animals whilst it is very low in growing-fattening ones (Kidder \& Manners, 1978). Thus, the similar glucose and galactose apparent absorption values observed after the ingestion of the four experimental diets suggested the absence of any apparent effect of all three probiotics on lactose digestion in individuals having enough endogenous lactase activity. Previously we demonstrated that in growing-fattening pigs Sporolactobacillus $\mathbf{P} 44$ strongly increased apparent absorption of glucose and galactose from the same diet (Rychen \& Simões Nunes, 1993). Furthermore, such effects disappeared immediately after interruption of the addition of the microorganisms to the diet, indicating absence of remnant effects of ingested bacteria after supplementation interruption. This suggests that the presence of the added bacteria in the intestinal lumen was fundamental to the observed modifications in apparent absorption. In the present study the effect on AN apparent absorption of Sporolactobacillus P44 ingestion was of the same magnitude for both the initial and final test meals, suggesting relatively short-term adaptation of the mechanisms involved.

Gastric, duodenal and jejuno-ileal $\mathrm{pH}$ values for both weaners and growing-fattening pigs were not modified by any of the bacteria or bacterial combinations studied (G. Rychen and C. Simões Nunes, unpublished results).

Sporolactobacillus is a soil bacterium and has been primarily selected because of its sporulation capacity and some likeness with lactobacilli. However, Sporolactobacillus P44 is a lactose-negative strain (Belville, 1990). Nothing is known about the eventual gutcolonizing capacity of the strain.

The beneficial effect of yoghurt on lactose digestion in humans (Kim \& Gilliland, 1983; Garvie et al. 1984; Kolars et al. 1984; Marteau et al. 1990) was also demonstrated in lactase-deficient individuals.

In the present study Sporolactobacillus P44 (SP) supplementation significantly altered the amino- $N$ levels in the portal vein whilst the increased apparent absorption observed after $\mathrm{AC}$ and $\mathrm{AB}$ at the doses used were very small and without statistical significance.

The effect of Sporolactobacillus P44 (SP) on amino-N apparent absorption confirmed the same observation previously reported in growing-fattening pigs (Rychen \& Simões Nunes, 1993). Mechanisms involved in such an effect could be either a stimulation of endogenous proteolytic activity, an effect of supplemented bacterial proteolytic activity, a reduced catabolism of free amino acids in the intestinal lumen or a combination of all three. This 
question calls for further experimental work. As emphasized before, strong precautions were taken to avoid, before feed ingestion, either a decrease in added bacteria or in subsequent bacterial metabolic activity. Determinations of levels of bacteria and free nutrients in the stored diets confirmed that the in vivo observations were a result of the added bacteria ingestion.

In conclusion, this study demonstrated that ingestion by the piglet of a diet supplemented with $10^{7}$ cfu Sporolactobacillus P44/g significantly increased apparent absorption of AN, estimated by porto-arterial differences during the first six postprandial hours. Apparent absorption of G, Gal and LA were not modified by any of the added bacteria.

It would be of great interest to quantify such absorptive phenomena by the use of simultaneous determinations of portal blood flow and porto-arterial concentration differences. The study of the mechanism involved in the observed phenomena should also be undertaken.

The authors thank Anne Colle, P. Robin and Valérie Wirth for skilful technical assistance.

\section{REFERENCES}

Ayebo, A. D., Angelo, I. A. \& Shahani, K. M. (1980). Effect of ingesting Lactobacillus acidophilus milk upon fecal flora and enzyme activity in humans. Milchwissenschaft 35, 73-84.

Barrow, P. A., Brooker, P. E., Fuller, R. \& Newport, M. J. (1980). The attachment of bacteria to the gastric epithelium of the pig and its importance in the microccology of the intestine. Journal of Applied Bacteriology 48, 147-154.

Belville, C. (1990). Influence du bacille sporulé P44 sur la digestibilité du lactose chez les rats gnotoxéniques (Influence of sporulated Bacillus P44 on lactose digestibility in gnotoxenic rats). In Mémoire Ingénieur Université Aix-Marseille I. Aix: University of Aix.

Besnier, M. O., Bourlioux, P., Fourniat, J., Ducluzeau, R. \& Aumaître, A. (1983). Influence de l'ingestion de yogourt sur l'activité lactasique intestinale chez des souris axéniques ou holoxéniques (Influence of yoghurt ingestion on axenic and holoxenic mice intestinal lactase activity). Annales de Microbiologie 134, $219-230$.

Fuller, R. (1992). History and development of probiotics. In Probiotics - The Scientific Basis, pp. 1-7 [R. Fuller, editor]. London: Chapman \& Hall.

Garvie, E. I., Cole, C. B., Fuller, R. \& Hewitt, D. (1984). The effect of yoghurt on some components of the gut microflora and on the metabolism of lactose in the rat. Journal of Applied Bacteriology 56, 237-245.

Goldin, B. R., Swenson, L., Dwyer, J., Sexton, M. \& Gorbach, S. L. (1980), Effect of diet and Lactobacillus acidophilus supplements on human fecal bacterial enzymes. Journal of the National Cancer Institute 64, 255-261.

Hill, I. R., Kenworthy, R. \& Porter, P. (1970). Studies of the effect of dietary lactobacilli on intestinal and urinary amines in pigs in relation to weaning and post-weaning diarrhoea. Research in Veterinary Science 2, $320-326$.

Kidder, D. E. \& Manners, M. (1978). Digestion in the Pig. Bristol: Scientechnica.

Kim, H. S. \& Gilliland, S. E. (1983). Lactobacillus acidophilus as a dietary adjunct for milk to aid lactose digestion in humans. Journal of Dairy Science 66, $959-966$.

Kolars, J. C., Levitt, M. D., Aouji, M. \& Savaiano, D. A. (1984). Yogurt, an autodigesting source of lactose. New England Journal of Medicine 5, 1-3.

Marteau, P., Flourie, B., Pochart, P., Chastang, C., Desjeux, J. F. \& Rambaud, J. C. (1990). Effect of the microbial lactase (EC 3.2.1.23) activity in yoghurt on the intestinal absorption of lactose: an in vivo study in lactasedeficient humans. British Journal of Nutrition 64, 71-79.

Muralidhara, K. S., Sheggeby, G. G., Elliker, P. R., England, D. C. \& Sandine, W. E. (1977). Effect of feeding lactobacilli on the coliform and lactobacillus flora of intestinal tissue and feces from piglets. Journal of Food Protection 40, 288-295.

Nguyen, T. H., Duperray, J., Eckenfelder, B., Lecamp, B., Lefrançois, S., Levesque, A., Nebout, J. M., Ridremont, B., Salle, F. \& Sergheraert, R. (1988). Quelques probiotiques facteurs de croissance (Some probiotic growth factors). Revue d Alimentation Animale 3, 31-37.

Palmer, D. W. \& Peters, T. (1969). Automated determination of free amino groups in serum and plasma using 2,4,6-trinitrobenzene sulfonate. Clinical Chemistry 15, 891-901.

Pusztai, A., Grant, G., King, T. P. \& Clarke, E. M. W. (1990). Chemical probiosis. In Recent Advances in Animal Nutrition, pp. 47-60 [W. Haresign and D. J. A. Cole, editors]. London: Butterworths.

Ratcliffe, B., Cole, C. B., Fuller, R. \& Newport, M. J. (1986). The effect of yogurt and milk fermented with a porcine intestinal strain of Lactobacillus reuteri on the performance and gastrointestinal flora of pigs weaned at two days of age. Food Microbiology 3, 203-211. 
Rérat, A., Simões Nunes, C., Vaissade, P. \& Roger, L. (1987). Comparison de deux techniques d'estimation (ninhydrine vs. TNBS) de l'azote des acides aminés circulants appliquées à l'étude de l'absorption intestinale de solutions d'acides aminés libres ou de petits peptides (Comparison of two techniques (ninhydrin vs. TNBS) for the estimation of amino-nitrogen from blood amino acids applied to the study of intestinal absorption of free amino acids or of small peptides). Reproduction Nutrition Développement 27, 955-966.

Rychen, G. \& Simões Nunes, C. (1993). Effects of a microbial probiotic (Sporolactobacillus P44) on postprandial porto-arterial concentrations differences of glucose, galactose and amino-nitrogen in the growing pig. Reproduction, Nutrition, Development 33, 531-539.

Schaafsma, G., Deriks, P., Dekker, P. R. \& Waard, H. (1988). Nutritional aspects of yogurt. Microbial lactase activity and digestion of lactose. Netherlands Milk and Dairy Journal 42, 121-134.

Simões Nunes, C. \& Malmlöf, K. (1992a). Effects of guar gum and cellulose on glucose absorption, hormonal release and hepatic metabolism in the pig. British Journal of Nutrition 68, 693-700.

Simões Nunes, C. \& Malmlöf, K. (1992b). Interorgan movements of amino acid in the pig: effects of dietary fibres. Amino Acids 2, 77-86.

Simões Nunes, C., Rérat, A., Galibois, I., Vaugelade, P. \& Vaissade, P. (1989). Hepatic and gut balances of glucose, amino-nitrogen, ammonia and urea in the pig after ingestion of casein or rapeseed proteins. Nutrition Reports International 40, 901-907.

Snedecor, G. W. \& Cochran, W. G. (1967). Statistical Methods. Ames: Iowa State University Press.

Vanbelle, M., Teller, E. \& Focant, M. (1990). Probiotics in animal nutrition: a review. Archives of Animal Nutrition 7, 543-567. 